\title{
Blended Learning Outcomes in Academic and Professional Writing
}

\author{
Catherine Owens, Robert Burgess \\ School of Liberal Arts, Shinawatra University, Thailand \\ owens.c@siu.ac.th
}

\begin{abstract}
Much has been written about the potential of online learning. Advantages discussed in the literature include practical considerations such as career preparation, convenience, and savings in time and money, the ethical benefit of open access and the environmental one of reduced paper and printing; learning benefits such as improved creativity and support for a more learner centered environment, learner autonomy, and the establishment of standards. This study documents the learning outcomes of 28 undergraduate students studying Professional and Academic Writing in a blended learning environment. Outcomes reflect gains in academic English writing skills, with specific reference to the use of the process approach to writing. Evidence from students'e-portfolios provides a rich source of learners' engagement in the planning, drafting, revising and presenting steps of paper completion. Further evidence shows how students develop information literacy through the use of the online learning materials. The instructional design features of particular tasks along with the e-portfolio used for formative evaluation are also analyzed for their contributions to the learning outcomes.
\end{abstract}

Keywords: Blended learning, e-Portfolio, Community of Inquiry, instructional design

\section{Introduction}

As online courses become established in corporate training and in higher education, and move into the K-12 systems of North America and Europe, educators have begun to investigate their effectiveness (Shea, GozzaCohen, Uzuner, Mehta, Valtcheva, Hayes \& Vickers, 2011; Graham, 2013; Partridge, Ponting \& McCay, 2011). Course instructors and designers need data on how students are using online material, the learning outcomes gained from the material, and both students' and teachers' levels of satisfaction with the online experience. One of the main concerns in students' use of online courses is self-direction. Allen and Seaman (2013) noted that online learners' need for self-discipline in their pursuit of studies by distance was perceived as even more of a threat by educators in 2012 than it was in 2007. In response to this perception, teachers have tried innovative learning arrangements to experiment with variations on a purely online or distance model. One of those variations is blended learning, a model that has been discussed since the turn of the 21st century. Blended learning refers to the use of online learning resources in the classroom. The blending can vary in the amount of input source, as in, for example, $40 \%$ teacher-led instruction and $60 \%$ online tasks. Current practice shows that blended learning is the use of online learning material in a classroom by students under the guidance of a teacher (Peterson \& McGuire, 2014; Picciano, Dziuban and Graham, 2014).

The blending of the online materials delivery with a teacher in some proportion of face-to-face instruction is relevant to instructional designers, educational researchers, program administrators and students who embrace the technology (Graham, 2013; Garrison and Vaughan, 2008; Graham and Dziuban, 2008).The concept of blended learning is an easily foreseen consequence of instruction based on online course delivery and outcomes, while its strength as a learning paradigm lies in the ways it impacts how learning happens and how it maximizes effectiveness (Swan, Garrison \& Richardson, 2009). Much has been written about the benefits in learning outcomes, knowledge acquisition, and information literacy that accrue from the use of blended learning (Means et al., 2010; Shea \& Bidjerano, 2011; Bliuc, Goodyear \& Ellis, 2007; Twigg, 2004). Blended learning has been a growing practice in tertiary education since the early 2000's when educators saw that the physical presence of a teacher in classrooms, face to face with the students, could systematically and effectively augment online courses. A large number of studies conducted in the first decade of the $21^{\text {st }}$ century found evidence of how students used online materials, what their levels of satisfaction were and how effectively they learned the content. Research into this paradigm has necessitated the development of new 
frameworks for the systematic investigation of such courses. The Community of Inquiry (CoI), developed by Garrison, Anderson and Archer in 2000, has been widely accepted as one such framework. The CoI model posits that learning takes place with the interaction in the learning environment of three presences: teaching presence, social presence and cognitive presence. The analysis of how these presences operate in specific learning situations and with certain types of instructional designs is ongoing.

The blended learning model includes face-to-face student-teacher interaction for guidance, monitoring, and feedback. It addresses one of the most important concerns of all teachers: ensuring that students are in fact maximizing their individual potential in the classroom. In traditional language classrooms this can be problematic when administrative requirements override educational best practice. Problems can occur, for example, when students are not properly evaluated and streamed, when class composition and sizes are dictated on financial, not pedagogical grounds, or when national or cultural norms of pass/fail standards affect student promotion through systems. Blending the online course materials with a teacher allows students to progress at their own rates independently, using the classroom interaction for collaborative work or to consult with the teacher for individual feedback. The CoI framework permits investigation into how courseware involves teaching, social or cognitive presence by identifying the parameters as learners use the course material. A self-evaluation form itemizing some of these parameters is a useful tool in having students reflects on their use of the learning materials, their ability to socialize in pursuit of learning objectives and their recognition of teacher input. Deep learning is believed to accrue from the interaction of these three presences. Further support for ways to compel deep learning derives from the recognition of best practice in tertiary education. The concept of best practice is grounded in the work of Chickering and Gamson in 1987 (Kuh et al., 2010; Thomas 2012), who argued that such practices:

- encourage student - faculty contact

- encourage cooperation among students

- encourage active learning

- give prompt feedback

- emphasize time on task

- communicate high expectations

- respect diverse talents and ways of learning

Incorporation of the above instructional principles into teaching practice is a familiar goal in educational quality assurance exercises worldwide. Coupled with the need for analyses of learning outcomes, learner satisfaction and faculty perceptions of using online courseware and blended learning, a robust basis for the investigation of a particular learning situation emerges. The present study seeks to clarify the use of blended learning in an undergraduate academic and professional writing course with direct reference to the teaching presence inherent in the courseware and the communication of high expectations, using action research. It seeks to answer the research questions:

- How does this course in Academic and Professional writing communicate high expectations?

- How do students respond to the high expectations?

- How does teaching presence in this course influence student outcomes?

\section{Literature Review}

A comprehensive definition offered by Bliuc, Goodyear and Ellis (2007) explains that blended learning is a form of instruction where students and teachers engage in both physical and remote interactions systematically in their use of online learning resources. Other familiar terms that combine online learning with classroom presence include the flipped classroom and hybrid learning, both used with some variance in meaning and acceptability. Blending a teacher with online course materials has resulted in instructors' investigations into how and what kinds of mediation optimize the learning potential (Graham, 2013; Garrison and Vaughn, 2008; Graham and Dziuban, 2008). Blended learning has been investigated in research at the secondary (Larson \& Murray, 2008) and tertiary levels, in business (Beckem \& Watkins, 2012) science (McDonald, Straker, Schlumpf \& Plack, 2014) and humanities courses, with specific populations (Shea, 2007) and longitudinally across tertiary institutions (Shea, Fredericksen \& Pickett, 2001). Many of the studies focus 
on student satisfaction (Dziuban, Moskal, Brophy-Ellison \& Shea, 2007; Bauk, 2015; Carter, 2013), while others investigate particular types of presence and their effects on learning outcomes (Wang \& Chen, 2008; Ice, Curtis, Phillips \& Wells, 2007; Garrison, 2007). Numerous articles report that the design of courseware, tasks and activities can affect active learning (Bower, Dalgarno, Kennedy, Lee \& Kenney, 2015; Beckem \& Watkins, 2012; McGee \& Reis, 2012).

Action Research: Action research has been a useful paradigm for a wide variety of research investigations. In 1995, Masters wrote a history of action research giving some of the foundational tenets of the practice. Kemmis and McTaggert compiled the Action Research Planner in 1982, providing a set of principles for use by teachers seeking greater insight into classroom events and their own practices. As Lingam (2012) points out, undertaking action research permits practitioners to review their own methods and techniques in light of their approach, training or ideology, and as a way to change how they use their classrooms, and how they comprehend their classroom activity. Zuber-Skerrit (2001) presented a paper wherein he claimed that action research and action learning was confirmed activities in social science, useable in the research and development areas of business and the public sector, as they could provide longer-lasting results and more appropriate insights than the usual forms of investigation and education. Action research as a practice is associated with Kurt Lew in, the American psychologist who worked in the psycho-social domain in the 1940 's, theorizing about group dynamics, management and productivity. Waters-Adams (2006) argues that the use of action research allows for observation and reflection on the effects of modifications in teaching practice. In his view, action research requires implementation of an action, which can be the catalyst to further modification, or could shed more light on the complexity of the learning event. Across the field of applied linguistics and pedagogy, action research has been used to build awareness and/or recognition of classroom practice, with the subsequent use of data and/or observation to form the basis for making change (Fareh \& Saeed, 2011; Atay, 2006)

Community of Inquiry: Garrison and Archer have been writing about their research focusing on the use of online learning and its effects since 2001. They promoted the idea of the community of inquiry as a set of parameters to explain how learning takes place. Their contention was that online learning offered potential for participants in the learning process to take part both affectively and interactively, enveloped in a community of inquiry (Rourke, Anderson, Garrison and Archer, 2001). They posited a community of inquiry as the impetus for the instructor and learners to work communally with computer-mediated and instructional inputs to build knowledge through constructivism (Garrison, Anderson \& Archer, 2000; Rourke et al., 2001; Shea \& Bidjerano, 2011). Its application to blended learning and the classroom interactions necessary for learning to take place comprise a key point of interest to the online course developer. With reference to the presumed loss of interpersonal interaction in using online learning materials, researchers looked carefully at how a social presence can arise. Relying on an analysis of the various definitions, Kim (2011, as cited in Kim, Kwon \& Cho, 2011) viewed social presence as a construct that reflects group dynamics - taking into account the way group members relate to one another, along with the bonds and emerging alliances that result from their group membership. In support of the blended learning approach, Bower and colleagues note that the formation of learning groups or study teams may not inherently result in stronger social bonds, and so teacher demands for social cohesion, or instructional methods for forming united teams and group projects needing collaboration need to be activated (Bower et al., 2015).

According to Akyol, Garrison and Ozden (2009, p. 1834), the framework provides order and guidance into the complexities and dynamics of online and blended learning environments. The philosophical premise of the framework is a collaborative constructivist approach to teaching and learning. The framework implies that a worthwhile educational experience is embedded within a community of inquiry that is composed of teachers and students - the key participants in the educational process. The CoI framework is conceived as the interaction of three presences: social presence, cognitive presence and teaching presence. Under this framework, as Akyol et al. (2009) claim, the way the three presences work together may have an effect on the depth of learning (Akyol, Garrison and Ozden, 2009). The present study looks at the outcomes which appear to reflect deep learning, encouraged by high expectations, promoted by a set of learning tasks which require cognitive engagement and monitored with teacher intervention to provide feedback and encouragement when needed. 


\section{Methodology}

This project adopted a collective case study methodology, using a standard case study data collection and analysis approach as outlined by Yin (2014). Several sources of data were collected from each case, including: (a) a pre-observation teacher-documented overview of the case as it had been implemented in the past, (b) pre-observation teacher notes in order to determine the rationale for the designs as well as teachers' insights into the blended synchronous learning approach, (c) researcher observations of the lessons, (d) postobservation student survey responses, (e) post-observation teacher interviews (Data collection is still in process). Teaching presence has been defined as "the design, facilitation and direction of cognitive and social processes for the purpose of realizing personally meaningful and educationally worthwhile learning outcomes" (Anderson, Rourke, Garrison \& Archer, 2001, p. 5). For the purposes of this paper, personally meaningful and educationally worthwhile learning outcomes are reflected in:

- high expectations as evidenced in workload/effort and quality of submissions

- student perceptions of peer and teacher interactions

- student perceptions of interaction with course content

- student perceptions of interaction with delivery system

- evidence of the 'flipped' classroom

The research sample consisted of 28 undergraduate students at a small international university in Thailand. The students were studying in the fields of Information Technology (1), Business Administration (14), and Management Technology (13). Twenty-seven were in their third year of studies and one was in her second year. The sample included eleven Thai nationals, eight Myanmar nationals, six Bhutanese nationals, two Nepalese nationals, and one Chinese national. Data was collected and analyzed from the students' online portfolios and self-evaluation forms, along with the final grades earned by these students for academic and professional written reports and attendance/participation. The self-evaluation forms were provided to students at two points during the course - at the mid-semester break and after the course were completed. The data was collected and collated in an Excel spreadsheet and analyzed using the Excel CORREL function. The course teaching Academic and Professional Writing is named Mastering Academic English (MAE). It employs a sophisticated pedagogical and instructional design. Language skills are integrated across tasks, with increasing linguistic and cognitive demands. It is content-based in that it uses contextually relevant, real world tasks in the classroom environment. It features a flexible blended learning format that encourages learner independence. The asynchronous approach to content delivery is ideally suited to the implementation of the 'flipped' classroom learning environment. MAE is a 45-hour course delivered over 16 weeks. The first half of the course focuses on academic writing and the second half focuses on professional writing. There are no formal exams. Students are evaluated formatively through submissions to their online portfolio as follows:

Table 1: Course Assessment

\begin{tabular}{llll}
\hline Activity & Assessment Method & Assessment & \\
\hline & & Marks & Percentage \\
Class Attendance & Attendance and Participation records & 16 & 10 \\
Portfolio & Labels, organization, maintenance & & \\
Notes & Grades for Quality of notes & 15 & 30 \\
Peer Review & Grades for attention to peer drafts & 15 & \\
Vocabulary & Grades for complete vocabulary lists & 15 & \\
Academic Writing + Portfolio & Drafts \& pre-set criteria & 100 & 30 \\
& & & \\
Professional Writing + Portfolio & Curriculum Vitae & 20 & 30 \\
& Statement of Purpose & 20 & \\
& Letter of Intent & 10 & \\
\hline
\end{tabular}


MAE applied a blended learning model of content delivery. The delivery platform uses HTML, PHP, Java script and a Mysql database. The course is accessible online to any student with a computer or mobile device and the appropriate login credentials in an asynchronous delivery mode. Students are encouraged to 'flip' the classroom in that they come to class already having read, taken notes and built their vocabulary from the online readings and lectures. Students are ready then to develop and extend their knowledge through discussion, seminars, paper drafting and peer reviews. Teaching faculty met the students face-to-face (teacher present in the classroom) on alternate weeks. Online classes with teacher interaction through Skype (with students present in the classroom) were also held on the other weeks. Weekly course content was provided online and consisted of Objectives, Seminar, Lecture, Reading, Writing and Vocabulary. Students could access the material at anytime, anywhere, as long as they had an Internet connection. The faculty teaching the course was the authors of this study. They are also the developers of the blended learning platform used in this course. The particular course is one of a suite of five core English language courses required by the undergraduate curriculum. The MAE course in this study has been run as a credit-bearing course six times over the past two years. It was assumed that communication of high expectations should be reflected in the course demand of a significant workload. Response to the high expectations was indicated by the effort to meet the demand by the subjects. Results can be quantified in terms of student submissions to their portfolios. Quality of student submissions is another avenue of investigation.

\section{Results}

Table 2: Total Student Submissions

\begin{tabular}{lllllll}
\hline & Notes & $\begin{array}{l}\text { Vocab } \\
\text { Logs }\end{array}$ & $\begin{array}{l}\text { Academic } \\
\text { Drafts }\end{array}$ & $\begin{array}{l}\text { Professional } \\
\text { drafts }\end{array}$ & $\begin{array}{l}\text { Reviews/ } \\
\text { Evaluations }\end{array}$ & Total \\
\hline Maximum & 29.0 & 14 & 14 & 13 & 7 & 68.0 \\
Minimum & 9.0 & 0 & 4 & 1 & 1 & 29.0 \\
Average & 20.8 & 7.4 & 8.2 & 6.6 & 3.1 & 45.6 \\
\hline
\end{tabular}

$\mathrm{N}=28$

Outcomes related to how much students are capable of producing are reflected in the number of assignments, notes, drafts, and reports students submitted to their portfolios. On average, students submitted 45.6 pieces of data to their portfolios (Table 2). This included 20.8 sets of notes on lectures and readings, 7.4 vocabulary logs, 8.2 academic drafts and 6.6 professional writing drafts. This is consistent with best practice goals, which hold that students should be held to high standards.

Table 3: Correlations of Submissions and Scores in Course

\begin{tabular}{llll}
\hline Submissions & $\underline{\mathbf{r}}$ & $\mathbf{p}$ & Significance \\
\hline Total & 26 & 0.656254655 & $<.05$ \\
Notes & 26 & 0.557416669 & $<.05$ \\
Vocabulary & 26 & 0.201808042 & NS* \\
Academic Drafts & 26 & 0.27913287 & NS* \\
Professional Drafts & 26 & 0.562051708 & $<.05$ \\
Reviews & 26 & 0.520078504 & $<.05$ \\
\hline
\end{tabular}

${ }^{1} \mathrm{~N}=28$

The results (Table 3) show that students' completion and submission of work to their portfolios correlates significantly $(\underline{p}<.05)$ with their grades in this course. This was true with the total submissions, notes, 
professional drafts and reviews, but not vocabulary and not academic drafts. To present the subjects' impressions of those outcomes, responses to the self-evaluation forms are reported in Table 4. Answers were given using a five-point scale, where the higher end of the scale corresponds to greater agreement and the lower end of the scale corresponds to less agreement. Subject impressions of their personal productivity were also very positive. In the first seven weeks, 67.9 percent reported that they came to class prepared. Seventyone point four percent reported completing their vocabulary log, 89.3 percent reported they completed their readings, and 85.7 said they completed their assignments. Eighty-two point one percent felt that they took part in the class. Seventy-five percent believed that they took effective reading notes. Seventy-one point four percent reported that they took effective lecture notes.

Table 4: Subject Impressions of Productivity at Midterm

\begin{tabular}{lllllll}
\hline Rank & $\mathbf{5}$ & $\mathbf{4}$ & $\mathbf{3}$ & $\mathbf{2}$ & $\mathbf{1}$ & Total \\
\hline I & $\mathbf{\%}$ & $\mathbf{\%}$ & $\mathbf{\%}$ & $\mathbf{\%}$ & $\mathbf{\%}$ & $\mathbf{\%}$ \\
Came prepared & 28.6 & 39.3 & 21.4 & 3.6 & 7.1 & 100 \\
Completed vocabulary & 35.7 & 35.7 & 21.4 & 7.1 & 0.0 & 100 \\
Completed readings & 39.3 & 50.0 & 7.1 & 3.6 & 0.0 & 100 \\
Completed assignments & 46.4 & 39.3 & 14.3 & 0.0 & 0.0 & 100 \\
Took part in class & 35.7 & 46.4 & 10.7 & 7.1 & 0.0 & 100 \\
Took effective reading notes & 35.7 & 39.3 & 14.3 & 10.7 & 0.0 & 100 \\
Took effective lecture notes & 32.1 & 39.3 & 17.9 & 10.7 & 0.0 & 100 \\
\hline
\end{tabular}

$\mathrm{N}=28$

Table 5: Subject Impressions of Workload at Midterm

\begin{tabular}{lllllll}
\hline Rank & $\mathbf{5}$ & $\mathbf{4}$ & $\mathbf{3}$ & $\mathbf{2}$ & $\mathbf{1}$ & Total \\
\hline This course was & $\mathbf{\%}$ & $\mathbf{\%}$ & $\mathbf{\%}$ & $\mathbf{\%}$ & $\mathbf{\%}$ & $\mathbf{\%}$ \\
Challenging & 57.1 & 28.5 & 10.7 & 0 & 3.5 & 100 \\
Hard work & 57.1 & 25 & 17.8 & 0 & 0 & 100 \\
Helpful & 60.7 & 21.4 & 14.2 & 3.5 & 0 & 100 \\
Interesting & 42.8 & 32.1 & 21.4 & 3.5 & 0 & 100 \\
Valuable & 57.1 & 28.5 & 14.2 & 0 & 0 & 100 \\
Useful to other courses & 57.1 & 28.5 & 14.2 & 0 & 0 & 100 \\
\hline
\end{tabular}

$\mathrm{N}=28$

Subject impressions of the course and the workload were very positive. In the first seven weeks, 85.6 percent reported that the course was challenging and 82.1 percent felt that it was hard work. At the same time, 82.1 percent felt that it was helpful, 74.9 believed it was interesting while 85.6 percent felt that it was both valuable and useful in other courses at the university. 
Table 6: Subject Impressions of outcomes by the Midterm

\begin{tabular}{|c|c|}
\hline Things I learned to do: & Number of comments \\
\hline Improve vocabulary & 10 \\
\hline Write an academic paper & 9 \\
\hline Use outside sources & 7 \\
\hline Write a thesis statement & 6 \\
\hline Format (Word) & 6 \\
\hline Reference & 5 \\
\hline Draft separate versions & 4 \\
\hline Choose topic & 4 \\
\hline Write introduction & 4 \\
\hline Outline & 3 \\
\hline Set context & 3 \\
\hline Time management & 3 \\
\hline Responsibility for own learning & 2 \\
\hline Take notes & 2 \\
\hline Work with team members & 2 \\
\hline Follow instructions & 2 \\
\hline Argue + proof & 2 \\
\hline Plan & 2 \\
\hline Read interesting articles for paper & 1 \\
\hline Support thesis & 1 \\
\hline Do homework on time and precisely & 1 \\
\hline Paraphrase & 1 \\
\hline Use a website for help & 1 \\
\hline Avoid plagiarism & 1 \\
\hline
\end{tabular}

$\mathrm{N}=28$

In comments written in prose, students made 82 individual statements of what they had learned in the course. These comments ranged from improved vocabulary to time management to avoiding plagiarism. 
Table 7: Subject Impressions of What They Need to Do More of

\begin{tabular}{ll}
\hline I need to & Number of comments \\
\hline Learn vocabulary & 9 \\
Read and research more & 9 \\
Manage time & 8 \\
Come prepared & 4 \\
Pay attention in class & 3 \\
Work hard & 3 \\
Learn sentence structure & 3 \\
Take more/improve notes & 3 \\
Use website more & 2 \\
Stop being lazy & 2 \\
Discuss with group & 1 \\
Revise & 1 \\
Improve skills & 1 \\
Learn Microsoft Word & 1 \\
Become independent & 1 \\
Seek help outside class & 1 \\
Listen to teacher & \\
\hline Ne28 & 1 \\
\hline
\end{tabular}

$\mathrm{N}=28$

In comments written in prose, students made 52 individual statements of what they need to do to learn more in the coming weeks. These comments ranged from learn more vocabulary, to stop being lazy, to listen to the teacher.

\section{Discussion and Conclusion}

This study shows that students are capable of handling a substantial workload in a blended learning language course. They submitted numerous sets of notes, vocabulary logs, professional and academic writing drafts and peer and self-evaluations. It is believed that they completed this work with the expectation that they would receive teacher feedback, which would improve their performance and result in a higher grade. It is interesting to note that they were this productive even though the course was not evaluated through formal midterm or final examinations. Only one student submitted work for assessment well after the logical due date. That work was submitted solely to meet portfolio grading expectations, not for personal improvement. It would seem that the subjects were productive through a combination of reminding and deadline setting by the teacher, and intrinsic and extrinsic motivation by the student. This supports the idea that 1) deeper and more meaningful involvement with the learning materials would in fact yield better scores, 2) the task designs communicate a need for analysis and thoughtful reflection, and 3) the teacher is needed in the classroom to cajole, encourage and insist on performance. Through teaching presence, both in terms of task 
design and content demand, subjects demonstrated that their use of the course promoted deeper learning, as they were able to produce more relevant and higher quality writing as the semester went on. This was particularly true in the final professional report, the culmination of a four-week team project, where teams produced sophisticated and well-researched reports in response to a difficult challenge. The other aspect of teaching presence -- encouragement, monitoring and feedback -showed a degree of reduced need over the length of the course, in that subjects required less and less reminding and persuasion by the teacher as they became more independent in their use of the material.

Analysis of the actual submission for quality and depth of understanding is ongoing, but the initial impression of a strong cognitive presence is very well supported. Subjects submitted unique sets of notes and drafts, which indicates they are not copying from their friends. Over time, their notes showed a heightened understanding of the concepts and the issues presented in both the readings and the lectures. Notable is the fact that much of the content of these readings and lectures focus on the meta-language of writing and learning, reflecting and revision. This design is purposeful teaching presence, in that the instructional content provides input that clarifies what they need to use to improve their writing. Drafts of subjects' papers exhibited many of the issues inherent in undergraduate writing - lack of cohesion, inadequate proofreading for error in content and logic, and plagiarism. The teacher's feedback on these errors and how to correct them seemed to be instrumental in making these writers more responsible, more ambitious and more evaluative of their own efforts. Another element of instructional design contributed to strong outcomes. This was the format of the course, where the first half was devoted to the planning, drafting, revising and presentation of an academic paper based on the argument of a thesis of each student's choice. This is an inherently difficult task, and required a significant amount of feedback and revision for success. The second half was professional writing, an intrinsically less demanding and more concrete form of writing, which subjects saw as immediately useful - as many were applying for internships in the coming semester -- and thus, more intrinsically motivating.

The subject impressions of their productivity indicate that the flipped classroom model of teaching and learning was implemented in practice. They reported that they came to class prepared, that they had taken effective notes from lectures and readings, that they had completed their assignments and, most importantly, that they took part in class. The classroom activities, seminars, group-work and peer review were designed to allow students to extend what they had learned from the course materials before the scheduled class in the actual class. That is an important indication of a teaching presence. The subject responses to the course expectations were also very encouraging. They reported that the course was challenging and hard work. Yet they did not complain about the challenge. Instead they reported that the course was interesting, valuable and useful. Their understanding of the challenge is then reflected in their intentions for the rest of the semester. Clear evidence of their own improvement was not only visible to the teachers, but also to themselves, as they began to recognise the value of the e-portfolio as a record of their development. This speaks to a teaching presence that encourages self-direction, discipline and maximizing individual potential. It is particularly interesting to note that while vocabulary development was not correlated to grades in this particular course, it was one of the items that the largest number of subjects indicated that they had done. Vocabulary was also reported by the largest number of students as what they knew they needed to learn in the coming weeks. This again reflects a teaching presence that encourages self-direction, discipline and developing individual potential.

Limitations: The limitations inherent in this study are several, and may have affected the outcomes or the way the outcomes may be interpreted. The authors are themselves the course material writers, teachers and action researchers. This can impact the likelihood of success of a given methodology or set of materials, as the use of a course by its creators involves enthusiasm and engagement that may not occur with a third party teacher. Further, the students themselves were variable in their use of the materials and the online aspect of the lessons, which was evident in the way they did not seem to use the website as efficiently as they should have to support their work. Many of them wanted to rely solely on the teachers' feedback for correction and improvement. Students also may have done as much or similar amounts of work had the materials not been presented online, though the course developers believe that an online presence is more attractive to millennials, and will continue to be regarded as the modern way to learn. As this course has no formal exams, the grades are somewhat subjective, based on drafts, final papers, and collected notes. However, most 
writing courses are intrinsically subjectively graded, unless instructor's use blind double grading, which is not often possible with large classes. Subsequent investigation into the efficacy of the course and its outcomes could be compared to the course carried out with summative assessment.

\section{References}

Akyol, Z., Garrison, R. \& Ozden, M. Y. (2009). Online and blended communities of inquiry: Exploring the developmental and perceptional differences. The International Review of Research in Open and Distributed Learning, 10(6), 65-83.

Allen, I. E. \& Seaman, J. (2013). Changing Course: Ten Years of Tracking Online Education in the United States. Babson Survey Research Group and Quahog Research Group, LLC. Retrieved Aug 2014 at: http://www.onlinelearningsurvey.com/

Anderson, T., Rourke, L., Garrison, D. R. \& Archer, W. (2001). Assessing teaching presence in computer conferencing context. Journal of Asynchronous Learning Networks, 5(2), 1-17.

Atay, D. (2006). Teachers' professional development: partnerships in research. TESL-EJ, 10(2)

Bauk, S. I. (2015). Assessing students' perception of e-learning in blended environment: an experimental study. Procedia - Social and Behavioral Sciences, 191, 323-329

Beckem, J. M. \& Watkins, M. (2012). Bringing life to learning: immersive experiential learning simulations for online and blended courses. Online Learning, 16(5), 61-70.

Bliuc, A. M., Goodyear, P. \& Ellis, R. A. (2007). Research focus and methodological choices in studies into students' experiences of blended learning in higher education. Internet and Higher Education, 10, 231-244.

Bower, M., Dalgarno, B., Kennedy, G. E., Lee, M. J. W. \& Kenney. J. (2015). Design and implementation factors in blended synchronous learning environments: Outcomes from a cross-case analysis. Computers \& Education, 86, 1-17

Carter, M. (2013). A study of students' perceptions of the online component of a hybrid postgraduate course. Procedia - Social and Behavioral Sciences, 84, 558 - 568.

Dziuban, C., Moskal, P., Brophy-Ellison, J. \& Shea, P. (2007). Student satisfaction with asynchronous learning. Journal of Asynchronous Learning Networks, 11(1). Needham, MA: Sloan-C.

Fareh, S. \& Saeed, A. T. (2011). The teacher as researcher in the context of language teaching. ProcediaSocial and Behavioral Sciences, 15, 153-159.

Garrison, D. R. (2007). Online community of inquiry review: social, cognitive and teaching presence issues. Online Learning, 11(1)

Garrison, D. R., Anderson, T. \& Archer, W. (2000). Critical Inquiry in a Text-Based Environment: Computer Conferencing in Higher Education. The Internet and Higher Education, 2(2-3), 87-105

Garrison, D. R. \& Vaughan, N. (2008). Blended Learning in Higher Education: Framework, Principles, and Guidelines. San Francisco, CA: Jossey-Bass.

Graham, C. R. (2013). Emerging practice and research in blended learning. In M. G. Moore (Ed.), Handbook of distance education (3rd ed., pp. 333- 350). New York, NY: Routledge.

Graham, C. R. \& Dziuban, C. D. (2008). Core research and issues related to blended learning environments. In J.M. Spector, M.D. Merrill, J.J.G. Van Merrienboer, \& M.P. Driscoll Eds., Handbook of research on educational communications and technology (3rd ed.). Mahwah, NJ: Lawrence Earlbaum Associates.

Ice, P., Curtis, R., Phillips, P. \& Wells, J. (2007). Using asynchronous audio feedback to enhance teaching presence and students' sense of community. Online Learning, 11(2).

Kemmis, S. \& McTaggart, R. (1982).The Action Research Planner.Victoria, Deakin University Press.

Kim, J., Kwon, Y. \& Cho, D. (2011). Investigating factors that influence social presence and learning outcomes in distance higher education. Computers and Education, 57, 1512-1520

Kuh G. D., Kinzie, J., Schuh, J. H. \& Whitt, E. J. (2010). Student success in college: Creating conditions that matter. San Francisco: Jossey-Bass.

Larson, R. C. \& Murray, M. E. (2008). Open educational resources for blended learning in high schools: overcoming impediments in developing countries. Online Learning, 12(1) retrieved July 2015 at http://onlinelearningconsortium.org/read/journal-issues/

Lingam, G. I. (2012). Action Research: Promise and Potential for Improving Teacher Professional Practice and the Learning Organization. American International Journal of Contemporary Research, 2(4), 47-57 
Masters, J. (1995). The History of Action Research in I. Hughes (ed) Action Research Electronic Reader, The University of Sydney, online http://www.behs.cchs.usyd.edu.au/arow/Reader/rmasters.htmRetrievedMay 10, 2015

McDonald, P. L., Straker, H. O., Schlumpf, K. S. \& Plack, M. M. (2014). Learning partnership: Students and faculty Learning together to facilitate reflection and higher order thinking in a blended course. Online Learning, 18 (3). RetrievedJune 2015 at http://onlinelearningconsortium.org/read/journal-issues/

McGee, P. \& Reis, A. (2012). Blended course design : a synthesis of best practices. Online Learning, 16(4)

Means, B., Toyama, Y., Murphy, R., Bakia, M. \& Jones, K. (2010). Evaluation of evidence-based practices in online learning: a meta-analysis and review of online learningstudies. US Department of Education Office of Planning, Evaluation, and Policy Development. Policy and Program Studies Service. Retrieved July 2014 at: https://www2.ed.gov/rschstat/eval/tech/evidence-basedpractices/finalreport.pdf

Partridge, H., Ponting, D. \& McCay, M. (2011). Good Practice Report: Blended Learning. Australian Learning and Teaching Council. Retrieved Nov 2014 at : http://eprints.qut.edu.au/47566/1/47566.pdf

Peterson, L. A. \& McGuire, D. M. (2014). Gearing up for hybrid teaching and learning : Ch-Ch-Ch-Ch-Changes! Higher Learning Commission Annual Conference 2014 Collection of Papers.

Picciano, A., Dziuban, C. \& Graham, C. (Eds.) (2014). Blended learning: Research perspectives (Vol. 2). New York: Routledge.

Rourke, L., Anderson, T., Garrison, D. R. \& Archer, W. (2001). Assessing social presence in asynchronous textbased computer conferencing. Journal of Distance Education, 14(2). Retrieved April 23, 2004, from http://cade.athabascau.ca/vol14.2/rourke_et_al.html

Shea, P. (2007). Bridges and barriers to teaching online college courses: A study of experienced online faculty in thirty-six colleges. University at Albany, State University of New York: http://www.sunyresearch.net/hplo/wpcontent/uploads/2012/04/Bridges_and_Barriers_to_Teaching_Online_College_Courses_A_study_of_E xperienced_online_faculty_in_Thirty_Six_Colleges.pdf

Shea, P. \& Bidjerano, T. (2011). Understanding distinctions in learning in hybrid and online environments: an empirical investigation of the community of inquiry framework. Interactive Learning Environments. DOI:10.1080/10494820.2011.584320

Shea, P., Fredericksen, E. \& Pickett, A. (2001). Student satisfaction and reported learning in the SUNY Learning Network. The State University of New York.

Shea, P., Gozza-Cohen, M., Uzuner, S., Mehta, R., Valtcheva, A., Hayes, S. \& Vickers, J. (2011). The Community of Inquiry framework meets the SOLO taxonomy: A process-product model of online learning. Educational Media International, 48(2), 101-113

Swan, K., Garrison, D. R. \& Richardson, J. C. (2009). A constructivist approach to online learning: the Community of Inquiry framework. In Payne, C. R. (Ed.) Information Technology and Constructivism in Higher Education: Progressive Learning Frameworks Hershey, PA: IGI Global, 43-57

Thomas, L. (2012). What works? Facilitating an effective transition into higher education. Widening Participation and Lifelong Learning, 14(Special Issue Winter 2012-2013), 4-24. Retrieved Apr 30, 2013 at http://wpll-journal.metapress.com/content/3628kq59204r7107/fulltext.pdf

Twigg, C. A. (2004). Using Asynchronous Learning in Redesign: Reaching and Retaining the At- Risk Student. Sloan-C View: Perspectives in Quality On-Line Education, 8(1) (http://www.aln.org/publications/jaln/v8n1/v8n1_twigg.asp.

Wang, Y. \& Chen, V. D. (2008). Essential elements in designing online discussions to promote cognitive presence - a practical experience. Journal of Asynchronous Learning Networks, 12(3-4)

Waters-Adams, S. (2006). Action Research in Education. Retrieved Nov 9, 2014 from: http://www.edu.plymouth.ac.uk/resined/actionresearch/arhome.htm

Yin, R. K. (2014). Case Study Research Design and Methods. Sage Publications.

Zuber-Skerritt, O. (2001). Action Learning and Action Research: Paradigm, Praxis and Programs. Chapter One in Sankara, S., Dick, B. and Passfield, R. (Eds.) Effective Change Management through Action Research and Action Learning: Concepts, Perspectives, Processes and Applications. Southern Cross University Press, Lismore, Australia, pp. 1-20. 